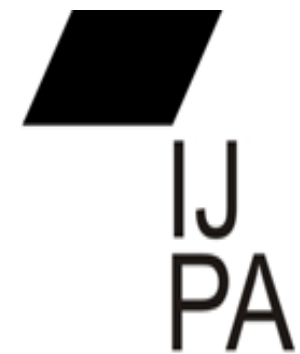

ISSN $2460=0369$

\title{
KALOBORASI DAN KOORDINASI PENYUSUNAN RBA UNIVERSITAS NUSA CENDANA TAHUN 2018
}

\author{
Erastus Dominggus Benu \\ M.N.C.B. Neolaka \\ Ajis S.Adang Djaha \\ Universitas Nusa Cendana Kupang \\ erastz@gmail.com
}

\begin{abstract}
Collaboration and coordination of the planning section with budget user units in terms of RBA preparation have not been established effectively and efficiently. Therefore, in this study researchers are interested in examining the collaboration and coordination built in preparing the University Budget Business Plan which is certainly an accumulation of programs and activities from all units in Undana as well as aspects that support and hinder the preparation of the RBA, so that the roots the problems in the drafting process have become more targeted and easily attainable. This study aims to identify the collaboration and coordination of the preparation of the Business Plan Budget (RBA) and to analyze aspects that support and hinder the preparation of the Business Plan Budget (RBA) of the University of Nusa Cendana in 2018. Research using qualitative descriptive methods. With data collection techniques of observation, interviews and documentation. collaboration and coordination that are built in preparing the University Budget Business Plan and aspects that support and hinder the preparation of the RBA, so that the root problems in the drafting process are more targeted and easily measured for achievement. The results of this study the preparation of the Budget Business Plan (RBA) is one of the important documents at the Public Service Board (BLU) satker. The formulation of the $R B A$ began after the Determination of Undana as a BLU satker and the preparation of the RBA required intensive collaboration and coordination between units with the University so that there was synchronization of programs and activities in the preparation of the University RBA according to the prevailing mechanism. Collaboration and coordination have not been carried out effectively and efficiently.
\end{abstract}

Key words: Collaboration, Coordination And Budget 
Abstrak, Kolaborasi dan koordinasi bagian perencanaan dengan unit-unit pengguna anggaran dalam hal penyusunan RBA belum terjalin secara efektif dan efisien. Oleh karena itu, dalam penelitian ini peneliti tertarik untuk meneliti kolaborasi dan koordinasi yang dibangun dalam menyusun Rencana Bisnis Anggaran Universitas yang tentunya merupakan akumulasi program dan kegiatan dari semua unit yang ada di Undana serta aspek-aspek yang mendukung dan menghambat penyususun RBA tersebut, agar akar permasalahan dalam proses penyusunan menjadi lebih terarah dan mudah di ukur ketercapaiannya. Penelitian ini bertujuan untuk mengengtahui kolaborasi dan koordinasi penyusunan Rencana Bisnis Anggaran (RBA) dan Untuk menganalisis Aspek-aspek yang mendukung dan menghambat penyusunan Rencana Bisnis Anggaran (RBA) Universitas Nusa Cendana tahun 2018. Penelitian menggunakan metode deskriptif kualitatif. Dengan teknik pengumpulan data observasi, wawancara dan dokumentasi. kolaborasi dan koordinasi yang dibangun dalam menyusun Rencana Bisnis Anggaran Universitas dan aspek-aspek yang mendukung dan menghambat penyususun RBA tersebut, agar akar permasalahan dalam proses penyusunan menjadi lebih terarah dan mudah di ukur ketercapaiannya. Hasil penelitian ini Penyusunan Rencana Bisnis Anggaran (RBA) merupakan salah satu dokumen penting pada satker Badan Layanan Umum (BLU). Penyusunan RBA ini mulai dilakukan setelah Penetapan Undana sebagai satker BLU dan Penyusunan RBA dibutuhkan kolaborasi dan koordinasi intensif antar unit dengan Universitas sehingga adanya sinkronisasi program dan kegiatan dalam penyusunan RBA Universitas sesuai mekanisme yang berlaku. Kolaborasi dan koordinasi belum dilakukan secara efektif dan efisien.

Kata kunci: Kolaborasi, Koordinasi Dan Anggaran

\section{PENDAHULUAN}

Kehadiran teknologi memberikan dampak global yang sangat dinamis penuh perubahan, kecepatan dan kompleksitas. Pesatnya perkembangan teknologi di era revolusi industri 4.0 sangat berpengaruh terhadap karakteristik pekerjaan, dimana ketrampilan dan kompetensi menjadi hal pokok yang perlu diperhatikan. Saat ini di Indonesia, era industri 4.0 sudah diterapkan dan sangat terasa pengaruhnya di masyarakat. Segala macam kegiatan sudah dinyatakan dalam bentuk digitalisasi. Pekerjaan-pekerjaan yang menggunakan teknologi moderen akan dikerjakan oleh generasi milenial. Oleh karena itu, dapat dipastikan bahwa generasi milenial akan memainkan peran sangat penting dalam perkembangan dunia kedepan.

Perguruan Tinggi merupakan lembaga formal yang diharapkan dapat melahirkan tenaga kerja kompeten yang siap menghadapi industri kerja yang kian berkembang seiring dengan kemajuan teknologi. Keahlian kerja, kemampuan 
beradaptasi dan pola pikir yang dinamis menjadi tantangan bagi sumber daya manusia. Perguruan Tinggi juga diharapkan menjadi pelopor dalam berinovasi dalam berbagai aspek layanan terutama dalam layanan pendidikan (e-learning) dan layanan berbasis online lainnya dalam tata kelola pendidikan tinggi bagi seluruh civitas akademik dan steakholders lainya.

Keberadaan Universitas Nusa Cendana sebagai salah satu Perguruan Tinggi Negeri yang berada di wilayah Timur Indonesia memiliki tanggungjawab untuk ikut mencerdaskan kehidupan bangsa Indonesia terutama masyarakat yang berada di propinsi Nusa Tenggara Timur dan sekitarnya. Dengan menyadari semakin tingginya harapan pemerintah dan masyarakat Indonesia kepada perguruan tinggi dalam memberikan pendidikan kepada generasi penerus bangsa agar kompetitif, kreatif, dan inovatif di era disrupsi saat ini, maka Undana dituntut untuk ikut berevolusi dan didorong kesanggupannya untuk melakukan upaya transformasi digital dalam penyelenggaraan kegiatan tridharma dan pengelolaan perguruan tinggi. Sampai dengan saat ini Undana telah memiliki 59 Program Studi dengan 10 program studi diantaranya berada pada program pascasarjana. Terhitung sampai tahun 2019, jumlah lulusan Undana dari berbagai jenjang pendidikan sebanyak 67.541 orang lulusan yang kini bekerja di berbagai instansi pemerintah maupun swasta di seluruh wilayah Indonesia terutama di wilayah NTT.

Undana yang diijinkan secara penuh untuk menerapkan Badan Layanan Umum (BLU), maka sebagaimana yang di harapkan pemerintah bahwa setiap instansi BLU memprioritaskan peningkatan layanan kepada masyarakat. Hal ini dapat dilakukan karena pengelolaan keuangan BLU dapat dilakukan lebih fleksibel, berupa keleluasaan dalam mengelola seluruh Pendapatan Negara Bukan Pajak (PNBP) secara langsung baik yang bersumber dari mahasiswa, masyarakat maupun dari investasi juga kerjasama dan pengelolaan aset yang dimiliki agar dapat meningkatkan pelayananannya kepada masyarakat terutama mahasiswa dan stake holder lainnya. Pengelolaan Keuangan Badan Layanan Umum (PKBLU) merupakan konsep baru dalam pengelolaan keuangan negara. Fleksibilitas disini memberikan kewenangan kepada satker BLU untuk dapat mengunakan pendapatan secara langsung tanpa harus setor terlebih dahulu ke kas Negara melalui Kantor Pelayanan Perbendaharaan Negara (KPPN). 
Penggunaan teknologi informasi dapat digunakan sebagai alat bantu dalam menyusun sebuah RBA kolaboratif, Undana yang memiliki banyak unit pengguna anggaran sehingga sangat relevan dengan penggunaan teknologi sebagai media dalam merampungkan dokumen RBA. Selain menghemat waktu dan tenaga juga kemudahan akses berupa aturan atau kebijakan kepada seluruh elemen terkait penyusunan dokumen RBA tersebut. Apalagi banyak jabatan dalam lingkungan Undana yang diisi oleh para dosen, sehingga di sela-sela kesibukan melakukan kegiatan tridharma dapat juga menyelesaikan penyusunan dokumen RBA tersebut sesuai dengan waktu yang ditentukan.

\section{KAJIAN TEORITIS}

\section{a. Kolaborasi}

Kusnandar (2013), menyatakan Kolaborasi adalah bekerja sama khususnya dalam usaha penggabungan pemikiran. Hal ini sesuai dengan definisi kolaborasi sebagai jaringan atau distribusi informasi, sumberdaya, aktivitas dan kapabilitas organisasi dalam dua atau lebih sektor untuk bekerjasama mencapai tujuan yang tidak bisa dicapai jika bekerja sendiri-sendiri. Kolaborasi adalah praktek kerja dimana individu bekerja sama, untuk tujuan yang sama, untuk mencapai manfaat bisnis dengan maksud mencapai efisiensi dan efektifitas.

Kolaborasi menurut Ilza (2013), adalah suatu proses partisipasi beberapa orang ataupun kelompok organisasi untuk bekerja bersama mencapai hasil tertentu. Jadi, kolaborasi menurut adalah bentuk kerjasama untuk mencapai hasil yang diinginkan sekaligus melahirkan kepercayaan diantara pihak yang terkait.

\section{Karakteristik kolaborasi}

Carpenter (2009), ada 8 (Delapan) karakteristik kolaborasi antara lain: 1). Partisipasi tidak dibatasi dan tidak hirarkis. 2). Partisipan bertanggung jawab dalam memastikan pencapaian kesuksesan. 3). Adanya tujuan yang masuk akal. 4). Ada pendefinisian masalah. 5). Partisipan saling mendidik atau mengajar satu sama lain. 6). Adanya identifikasi dan pengujian terhadap berbagi pilihan. 7). Implementasi solusi dibagi kepada semua orang yang terlibat, dan 8). Partisipan selalu mengetahui perkembangan situasi. 


\section{Nilai Kolaborasi}

Ada sejumlah nilai yang menjadi dasar dalam melakukan kolaborasi. Nilai (value) tersebut harus menjadi pegangan bagi kolaborator sehingga apa yang menjadi tujuan bersama dapat tercapai. Menurut Djumara, (2008) terdapat tujuh nilai dasar (The seven core values) yang digunakan untuk mengembangkan hubungan kerja dengan konsep kolaborasi

\section{Bentuk - bentuk Kolaborasi}

Menurut Ahmadi (2004), terdapat tiga bentuk kolaborasi antara lain: 1) kolaborasi Primer. Ciri utama dari kolaborasi primer adalah bahwa Kelompok dan individu dalam kelompok dilebur menjadi satu. 2) Kolaborasi sekunder. Apabila kolaborasi primer karakteristik dan masyarakat primitif, maka kolaborasi sekunder bercirikan sebaliknya. Kolaborasi sekunder adalah khas pada masyarakat modern. 3) Kolaborasi Tertier. Berbeda halnya dengan tipe kolaborasi Primer dan Sekunder, Kolaborasi Tertier didasari oleh adanya konflik yang laten. Kolaborasi Tertier dilandasi oleh adanya sikap-sikap dari pihak-pihak yang melakukan kolaborasi adalah murni oportunis.

\section{b. Pengertian Koordinasi}

Koordinasi berasal dari kata coordination, co dan ordinare. Secara etimologi, koordinasi diartikan sebagai kegiatan yang dilakukan oleh berbagai pihak untuk saling memberi informasi dan mengatur (menyepakati) hal tertentu. Koordinasi sebuah kata yang mudah di ucapkan, tetapi sulit dilaksanakan.

Secara umum pengertian koordinasi adalah proses mensinergikan dan menyeimbangkan segala aktivitas dalam pekerjaan antara satu pihak dengan pihak lainnya untuk meraih tujuan semua pihak sekaligus tujuan bersama. Koordinasi sangat memerlukan komunikasi yang baik khususnya pada hal yang berkaitan dengan waktu, hal ini dikarenakan supaya apa yang di kerjakan sesuai dengan target yang di tetapkan dan tidak menghambat kerja dan tanggung jawab masing-masing. Komunikasi dalam koordinasi bertujuan untuk saling memberi informasi antar individu atau unit supaya tercipta sinegisitas dan tetap berpegang pada tujuan organisasi.

\section{Tujuan dan Manfaat Koordinasi}


Setelah mengetahui pengertian koordinasi menurut para ahli dan secara umum maupun khusus maka hal yang perlu diketahui selanjutnya adalah tujuan dan berbagai manfaat dari koordinasi. Sedikitnya ada 11 unsur tujuan dan manfaat koordinasi yang tercipta apabila keberhasilan koordinasi tercapai

\section{Macam-macam koordinasi}

Koordinasi bukanlah bagian yang terpisahkan dari integrasi, sinkronisasi dan simplifikasi yang sering di singkat KISS (koordinasi, Integrasi, Sinkronisasi dan Simplifikasi). Koordinasi wajibnya di laksanakan dari proses perumusan kebijakan, perencanaan, pelaksanaan sampai pada pengawasan dan pengendaliannya.

Menurut Husaini 2012, koordinasi dapat di bedakan atas (1) Koordinasi Hierarkis (Vertikal) yang dilakukan oleh Pejabat pimpinan dalam suatu instansi terhadap pejabat atau instansi di bawahnya, (2) Koordinasi fungsional yang di lakukan oleh pejabat atau suatu instansi terhadap pejabat atau instansi lain yang tugasnya saling berkaitan berdasarkan asas fungsionalisasi. Koordinasi ini dapat di bedakan atas koordinasi fungsional horizontal, diagonal dan territorial.

\section{Pendekatan Koordinasi}

Koordinasi yang dilaksanakan oleh seorang manajer atau pimpinan dalam mencapai tujuan organisasi perlu dilaksanakan dengan teknik pendekatan. Husaini Usman,(2012) terdapat tiga jenis pendekatan untuk mencapai koordinasi yang efektif dan efisien

\section{Jenis Koordinasi}

Pada umunnya koordinasi yang di terapkan dalam sebuah organisasi terbagi dalam 2 (Dua) bagian utama yaitu koordinasi internal dan koordinasi external. Husaini Usman (2012), koordinasi di jabarkan dalam 3 jenis koordinasi yakni (1) Koordinasi Vertikal yakni koordinasi yang dilakukan oleh pimpinan suatu unit atau organisasi kepada atasanya dan atau kepada bawahannya, (2) Koordinasi Fungsional yakni koordinasi yang di lakukan oleh pimpinan dengan pimpinan lainnya yang tugasnya saling berkaitan berdasarkan asas fungsionalitas, (3) Koordinasi Institusional yakni koordinasi yang dilakukan antar pimpinan organisasi yang menangani suatu urusan tertentu.

\section{Koordinasi yang efektif}


Koordinasi yang efektif sangat diperlukan dalam organisasi. Karena tanpa adanya koordinasi yang efektif maka pelaksanaan tugas-tugas dalam organisasi tidak dapat berjalan dengan lancar dan akhirnya dapat merugikan organisasi itu sendiri. Sebagai usaha untuk menciptakan koordinasi yang efektif dapat dilakukan metode koordinasi efektif. Agar koordinasi dapat dicapai dengan efektif dan memiliki potensi yang lebih berarti maka perlu diketahui metode untuk mencapai arah tersebut.

\section{Arti Koordinasi}

Menurut George R. Terry yang dikutip Manila (1996) berpendapat, bahwa koordinasi adalah pengerahan usaha-usaha yang teratur guna menciptakan jumlah, waktu, dan arah pelaksanaan yang tepat agar menghasilkan tindakan terpadu serta harmoni yang menuju ke arah sasaran yang telah ditetapkan. Selanjutnnya, Handoko (2003) mendefinisikan koordinasi (coordination) sebagai proses pengintegrasian tujuantujuan dan kegiatan-kegiatan pada satuan-satuan yang terpisah (departemen atau bidang-bidang fungsional) suatu organisasi untuk mencapai tujuan organisasi secara efisien.

\section{Prinsip Koordinasi}

George R Terry dan Stephene G. Franklin berpendapat bahwa prinsip dapat dirumuskan sebagai suatu pernyataan atau kebenaran pokok yang memberikan suatu petunjuk untuk berpikir atau bertindak. Pernyataan yang pokok memberitahukan hasil apakah yang dikemukakan bila prinsip itu diterapkan.

\section{c. Rencana Bisnis dan Anggaran (RBA)}

Berdasarkan Peraturan Menteri nomor 92/PMK.05/2011 tentang Rencana Bisnis dan Anggaran (RBA) serta Pelaksanaan Anggaran Badan Layanan Umum (BLU) merupakan dokumen perencanaan bisnis dan penganggaran yang beirisi program, kegiatan, target kinerja, dan anggaran suatu BLU. RBA juga memuat seluruh program, kegiatan, anggaran penerimaan atau pendapatan, anggaran pengeluaran atau belanja, estimasi saldo awal kas, dan estimasi saldo akhir kas BLU.

\section{d. Penelitian Terdahulu}

1. Raharja (2009) dengan penelitian tentang Kolaborasi sebagai strategi bisnis masa depan, menyatakan bahwa Hubungan antar organisasi masa kini dicirikan oleh kesalingtergantungan (interde-pendensi) satu sama lain karena situasi 
lingkungan yang dinamis dan terus berubah. Perubahan atau pergeseran dari sifat independen ke interdependen telah melahirkan berbagai pemikiran yang mengarahkan kepada model pengelolaan bisnis berdasarkan kemitraan, tidak lagi berdasarkan kompetisi (persaingan) dengan model analisis prepektif teori game. Hasil analisis teori game dalam penerapan teori kolaborasi dapat disimpulkan sebagai berikut; Pertama, dunia saat ini terus berubah dan relasi antar organisasi tidak lagi independen (saling bebas) tetapi bersifat interdependen (saling tergantung). Kedua, analisis teori game memperlihatkan bahwa ketika ada permasalahan dalam relasi antar organisasi, solusi yang dilakukan satu sepihak tidak akan menghasilkan keluaran yang optimal dan saling memuaskan, tetapi cenderung win lose. Demikian juga apabila permasalahan dalam relasi antar organisasi tersebut tidak diselesaikan sama sekali, maka cenderung lose-lose solution. Ketiga, penerapan konsep kolaborasi dan kompetisi memperlihatkan bahwa relasi antar organisasi dapat menciptakan situasi yang komplementer (saling melengkapi) yang pararel dengan sifat kolaborasi dimana relasi antar organisasi salingtergantung. Keempat, penerapan konsep kolaborasi mengharuskan terjadinya aliansi antara visi strategi perusahaan, relasi pelanggan, relasi tugas, hasil dan reputasi dalam suatu aliansi.

2. Pitri ( 2017). Melaksanakan penelitian tentang "Kolaborasi Pemerintah dan Masyarakat Dalam Penyelenggaraan Pendidikan: Pendidikan Khusus Di Provinsi Riau Tahun 2015-2016" . Tujuan dari penelitian ini adalah untuk mengetahui kolaborasi pemerintah dan masyarakat dalam penyelenggaraan pendidikan khusus di Provinsi Riau. Berdasarkan hasil analisis data hasil penelitian, maka dapat di tarik kesimpulan bahwa kolaborasi pemerintah Provinsi Riau dan masyarakat dalam penyelenggaraan pendidikan khusus tahun 2015-2016 belum berjalan efektif. Masih sangat minim program yang dijalankan secara kolaborasi antara pemerintah dan masyarakat. Para aktor yang terlibat dalam penyelenggaraan pendidikan khusus di provinsi Riau memainkan perannya masing-masing, namun mereka belum mampu memerankan secara optimal. 


\section{METODE PENELITIAN}

Penelitian ini menggunakan Metode deskriptif kualitatif dengan teknik pengumpulan data, berupa (1) wawancara, yaitu berupa kegiatan mewawancarai beberapa narasumber dan informan secara runtut berdasarkan instrument penelitian; (2) observasi, yaitu berupa kegiatan menentukan obyek fisik data; (3) penyampaian daftar pertanyaan/instrumen, yaitu dengan cara langsung di lapangan kepada para narasumber dan informan guna mengetahui mengetahui Bagaimana kolaborasi dan koordinasi penyusunan Rencana Bisnis Anggaran (RBA) dan Untuk menganalisis Aspek-aspek yang mendukung dan menghambat penyusunan Rencana Bisnis Anggaran (RBA) Universitas Nusa Cendana tahun 2018, (4) perekaman, yaitu merekam data yang diperoleh di lapangan; dan (5) pencatatan, yaitu mencatat secara ringkas hasil rekaman menjadi bahan tertulis.

Data dalam penelitian ini didapat secara lisan dan tulisan. Data lisan yang berupa hasil wawancara bersama narasumber dan informan, sedangkan data tertulis berupa struktur organisasi,laporan anggaran dan renstra.

\section{PEMBAHASAN}

\section{Kolaborasi dan Koordinasi Penyusunan RBA}

\section{Mekanisme Kerja BLU}

Salah satu upaya pemerintah untuk meningkatkan pelayanan kepada masyarakat adalah dengan adanya Undang-undang Bidang Keuangan Negara, ini merupakan bukti adaptasi berbagai pemikiran yang selama ini ada beserta perkembangannya. Dan lahirnya Undang-undang Perbendaharaan Negara, secara formal, menandai lahirnya suatu lembaga khusus yang kemudian dikenal dengan nama Badan Layanan Umum (BLU). Hingga tahun 2019, instansi Pemerintah yang menerapkan Pola Keuangan BLU mencapai 236 Instansi yang tersebar di berbagai daerah yang di kelompokan dala 4 kelompok yaitu kelopok Pendidikan, Kesehatan, pengelolaan Dana dan Pengelolaan wilayah atau kawasan. Terbitnya peraturan Menteri Keuangan Republik Indonesia tahun 2007 Nomor 119/ PMK.05/2007 menunjukan keseriusan pemerintah dalam meningkatkan layanan kepada masyarakat Jika diibaratkan Satuan Kerja Badan Layanan Umum (Satker BLU) dapat diibaratkan semi BUMN. Dikatakan semi BUMN karena Satker BLU juga diberikan keleluasaan atau fleksibilitas 
dalam tingkat tertentu. Fleksibilitas yang diberikan oleh Menteri Keuangan kepada Satker yang menerapkan Pola Keuangan Badan Layanan Umum, misalnya setoran Penerimaan Negara Bukan Pajak (PNBP) dari stakeholder tidak langsung disetorkan ke kas negara namun dapat langsung digunakan untuk memberikan pelayanan kepada stakeholder.

Pelayanan merupakan salah satu fungsi dari pemerintah, peralihan status menjadi BLU, menuntut Undana selaku instansi pemerintah untuk melakukan beberapa perubahan dalam diri Undana antara lain dengan adanya Peraturan Pemerintah Republik Indonesia Nomor 74 Tahun 2012 Tentang Pengelolaan Keuangan Badan Layanan Umum yang memuat tentang berbagai ketentuan yang wajib di penuhi oleh satuan kerja instansi pemerintah yang menerapkan pola keuangan badan layanan umum yang salah satu syarat mutlaknya adalah penyusunan Rencana Bisnis Anggaran (RBA).

\section{Mekanisme Perencanaan RBA}

Berkaitan dengan peningkatan layanan maka salah satu hal penting adalah melakukan perencanaan berbasis RBA. Meskipun perencanaan merupakan kegiatan yang sering dilakukan setiap tahun oleh seluruh bagian dan unit di Undana namun harus diakui masih menghadapi berbagai hambatan dan kendala, baik yang bersifat internal yakni standart kemampuan SDM dalam perencanaan maupun eksternal yakni kebijakan pemerintah. Apalagi yang di kerjakan dalam perencanaan sekarang berbeda dengan perencanaan tahun sebelum menjadi satker BLU, seketika menjadi satker BLU, maka pola perencanaan dan penganggaran juga turut berubah. Oleh karena itu, agar peningkatan kinerja layanan pada Undana dapat terwujud, diperlukan perencanaan yang matang. Dalam manajemen, perencanaan adalah proses mendefinisikan tujuan organisasi, membuat strategi untuk mencapai tujuan itu dan mengembangkan rencana aktivitas kerja organisasi. Perencanaan merupakan proses terpenting dari semua fungsi manajemen karena tanpa perencanaan fungsi-fungsi lain pengorganisasian, pengarahan dan pengontrolan tak akan dapat berjalan.

Tahun 2018 adalah tahun pertama Undana menerapkan pola perencanaan berbasis RBA, sesuai dengan mekanisme penyusunan anggaran, rancangan program dan kegiatan dalam RBA sudah di siapkan pada tahun sebelumnya. Dalam pelaksanaan program dan kegiatan dalam RBA tahun 2018 seyogianya di lakukan dari level terendah 
dalam organisasi Undana yakni pada level Prodi, UPT, subbagian dan pusat-pusat studi yang ada selayaknya mekanisme perencanaan pada lembaga pemerintahan yang dimulai dari tingkat desa, namun karena keterbatasan waktu dan keterbatasan pemahaman yang baik tentang RBA maka penyusunan RBA dilakukan pada level fakultas, Lembaga, Biro dan UPT, selanjutnya untuk penyusunan RBA dari level terendah dilakukan pada tahun 2019 dan seterusnya.

Sehubungan dengan kegiatan perencanaan RBA Undana yang menerapkan mekanisme perencanaan bottom-up maka sesungguhnya segala perencanaan dan penganggaran dalam urusan peningkatan layanan pada unit dilimpahkan sepenuhnya kepada unit tersebut sesuai dengan rencana strategis bisnis Undana dalam periode jangka menengah. Hal ini di lakukan supaya semua unit yang merupakan suatu kesatuan dan tidak terpisahkan dari Undana bersama-sama menuju satu tujuan dangan cara program dan kegiatan yang direncanakan dapat meningkatkan atau dapat mencapai tujuan unit sekaligus tujuan institusi secara keseluruhan.

\section{Penyusunan RBA Unit}

Penyusunan RBA Unit, sesuai dengan dokumen yang di peroleh bahwa tahun 2018 penyusunan RBA Undana tidak dilakukan dari unit terbawah dalam hal ini program studi (prodi) karena waktu penyusunan yang relative tidak terlalu lama sehingga disepakati untuk penyusunan RBA dimulai dari tingkat menengah yaitu Fakultas, Lembaga, Biro dan UPT. Hal ini disebabkan karena waktu semakin mendekat untuk diajukan ke kementerian, sehingga semua RBA sudah harus diterima universitas untuk dirampungkan dalam penyusunan RBA Universitas.

Dari hasil wawancara dengan dua Informan Undana ( Sanam dan Muskanan) menjelaskan bahwa proses perencanaan yang mengunakan metode bottom up belum di lakukan secara baik sesuai prinsipnya hal ini karena keterbatasan waktu pengajuan anggaran kegiatan pada tingkat kementerian. Perencanaan dengan mekanisme tersebut baru dilakukan pada tahun 2018 untuk perencanaan tahun 2019. Dalam mencapai tujuan dan sasaran seluruh program dan kegiatan di uraikan dalam bentuk Indikator. Hal ini di maksudkan untuk dapat mengukur capaian program dan kegiatan melalui indikator tersebut. Kemudian setelah itu barulah di turunkan pada unit untuk menyusun program dan kegiatan sesuaikan dengan indikator tersebut yang di sertakan juga dengan rencana 
aksi setiap indikator. Rencana aksi tersebut di buat untuk mengukur kinerja setiap triwulan sehingga digunakan oleh pimpinan Universitas sebagai pertimbangan pembayaran tunjangan kinerja setiap pegawai.

\section{Kendala yang di temui}

Tiap unit menyusun RBA mengikuti pemahamannya dan kala mengalami kesulitan dan dikoordinasikan dengan pihak fakultas, sementara pihak fakultas juga belum memahami penyusunan RBA dan harus ditanyai ke Universitas dalam hal ini bagian perencanaan. Hal ini disebabkan karena belum adanya kolaborasi dan koordinasi secara efektif.

Kendala lain yang ditemui adalah alokasi waktu dalam penyusunan RBA tidak secara memadai, pemahaman dan pengetahuan yang berbeda tentang RBA dapat menimbulkan multi tafsir sehingga tarik ulur waktu. Selain itu, penerapan BLU yang baru terjadi tahun 2017 belum dipahami secara baik mekanisme pengelolaannya oleh hampir semua komponen unit. Hal lain yang juga ikut berkontribusi dalam penyusunan RBA adalah tidak adanya SDM fungsional perencana. Selain itu juga, Tenaga SDM yang ada pada bagian Perencanaan tidak terlibat aktif dalam perumusan Renstra, sehingga dalam menjalankan tugas para tenaga kependidikan pada bagian perencanaan kurang kreatif dalam menginformasikan berbagai hal mengenai perencanaan RBA termasuk didalamnya tidak adanya sosialisasi Renstra dan pedoman penyusunan RBA yang benar.

\section{Pemahaman yang Keliru}

Penyusunan RBA sepertinya belum dianggap penting oleh kebanyakan Unit. Kolaborasi dalam penyusunan RBA unit masih dianggap hal yang biasa-biasa saja. Dalam penyusunan memang ada pertemuan untuk membahas program dan kegiatan yang akan di laksanakan seperti yang dilakukan oleh LP3M, tetapi setelah pembahasan tidak dapat merumuskan rencana tersebut dalam format RBA. sehingga operator sedikit kesulitan dalam melakukan banyak penyesuaian setelah di tolak oleh bagian perencanaan Universitas. Hal yang sama juga terjadi pada unit UPT Puskom, dalam penyusunan RBA pimpinan Unit tidak berkontribusi aktif sehingga seluruhnya dikerjakan oleh Kasubag dan operator RBA. Sedangkan kontribusi pimpinan hanya sebatas menandatangani usulan program dan kegiatan. Hal tersebut juga tercermin dari 
kecilnya besaran pagu UPT PUSKOM. penyusunan RBA dianggap biasa saja karena tidak mengetahui filosofi dari BLU, yang didalamnya harus menyusun RBA yang berbasis kinerja. Penyusunan RBA masih dianggap sama dengan penyusunan rencana kerja biasa yang berbasis anggaran tradisional sehingga terjadi banyak sekali perubahan selain yang di tolak oleh bagian perencanaan juga terjadi revisi yang berulang-ulang di saat pelaksanaan program dan kegiatan oleh unit.

\section{Pentingnya Kolaborasi dan Koordinasi}

Berdasarkan pengamatan peneliti dalam hal kolaborasi dan koordinasi penyusunan RBA Unit masih sangat kurang. Hal yang peneliti temukan berhubungan dengan kolaborasi dan koordinasi penyusunan RBA unit adalah kolaborasi yang masih belum lengkap dalam artian bahwa tidak semua elemen berkontribusi dalam penyusunan RBA. Pada dasarnya kolaborasi dan koordinasi sudah ada namun belum maksimal

Pada kenyataannya, tujuan Undana tidak mungkin di kerjakan oleh seseorang atau kelompok tertentu atau unit tertantu. Tidak semua urusan Undana dapat diselenggarakan sendiri oleh pimpinan Universitas, serta tidak mungkin tujuan Undana dapat terwujud jika ada unit/ fakultas yang melakukan program dan kegiatan sendirisendiri. Sehingga untuk efektivitas dan efisiensi diperlukan keterlibatan semua pihak yang diwujudkan dengan cara berkolaborasi atau kerjasama serta koordinasi yang baik dengan cara membangun tata kelola organisasi yang kolaboratif. Collaborative governance merupakan pengembangan cara dan bentuk pengorganisasian dan tindakan baru agar instansi pemerintah dapat mengatasi berbagai keterbatasan dalam penyelenggaraan pelayanan publik.

\section{Perencanaan Awal}

Sehubungan dengan penyusunan RBA yang bersifat kolaboratif dalam koordinasi yang baik bagi Institusi Undana maka perlu adanya pendekatan perencanaan dari bawah ke atas (bottom-up). Pendekatan ini merupakan upaya melibatkan semua pihak sejak awal, sehingga setiap keputusan yang diambil dalam perencanaan adalah keputusan mereka bersama, dan mendorong keterlibatan dan komitmen sepenuhnya untuk melaksanakannya. Kelemahan dari proses ini adalah memerlukan banyak waktu 
dan tenaga untuk perencanaan serta diperlukan pengembangan budaya kerja yang sesuai.

Dalam penyusunan RBA Undana yang menerapkan mekanisme perencanaan bottom-up maka dapat kita ketahui bahwa sebenarnya dalam sebuah organisasi yang baik dan berpeluang untuk terus maju adalah dengan memberikan kesempatan bagi unit -unit untuk merencanakan seluruh program dan kegiatan yang dapat meningkatkan pelayanan bagi masyarakat sekaligus juga meningkatkan pelayanan institusi secara keseluruhan.

\section{Pengajuan dan Penetapan RBA Unit}

Usulan RBA unit yang sudah di sepakati oleh seluruh komponen unit dan akan dilaksanakan pada tahun selanjutnya akan di konsolidasikan pada tingkat universitas, sekaligus di gabungkan menjadi RBA Universitas. Sedangkan dalam hal koordinasi dalam penyusunan RBA sebenarnya secara inplisit sudah terakomodir dalam kegiatan kolaborasi namun dalam kondisi Undana yang pada dasarnya baru dalam penerapan pola layanan BLU maka koordinasi juga mutlak dilaksanakan. Seluruh program dan kegiatan yang akan disusun oleh unit pengguna anggaran harusnya dikoordinasikan sehingga selain mencapai tujuan yang ditetapkan unit juga Universitas secara keseluruhan. Program dan kegiatan yang disusun harus di koordinasikan sehingga dapat menjawab tujuan dari unit berdasarkan visi dan misinya tidak keluar atau berbeda dengan tujuan yang ditetapkan oleh Universitas berdasarkan Rencana Strategis Bisnis dan Visi dan Misi Universitas.

\section{Penyusunan RBA Universitas}

Pengajuan RBA oleh satker BLU dilakukan secara berjenjang dengan terlebih dahulu diajukan kepada Menteri atau Pimpinan Lembaga untuk dibahas sebagai bagian dari Renstra-KL, RBA tersebut dilampiri dengan usulan standar pelayanan minimum dan biaya dari keluaran (output) yang akan dihasilkan.

RBA yang telah disetujui oleh Menteri atau Pimpinan Lembaga tersebut diajukan kepada Menteri Keuangan untuk dikaji kembali standar biaya dan anggaran BLU dalam rangka pemrosesan Renstra-KL, sebagai bagian dari mekanisme pengajuan dan penetapan APBN/APBD. Kemudian, BLU menggunakan APBN/APBD yang telah ditetapkan sebagai dasar penyesuaian terhadap RBA menjadi RBA definitif. 
Namun, sebelum di ajukan pada kementerian Ristekdikti, RBA yang di susun oleh Unit akan di konsolidasikan pada tingkat universitas. Dalam proses menyatukan berbagai usulan program dan kegiatan seluruh unit terkait, maka bagian perencanaan selaku tim teknis RBA Universitas akan melakukan verifikasi terhadap seluruh usulan. Hal ini dilakukan untuk meminimalkan kegiatan yang dianggap tidak sesuai dengan prinsip kegiatan berbasis kinerja. Kesatuan pemahaman terhadap filosofi BLU dan pemahaman yang baik tentang penyusunan RBA yang benar merupakan titik kunci dalam kemajuan satker BLU

\section{Kendala yang di hadapi}

Sejumlah kendala yang ditemui dalam penyusunan RBA Universitas antara lain penjelasan penyusunan RBA dan pelaksanaan penyusunan RBA dihadiri oleh orang yang berbeda. Operator bertugas secara teknik untuk menginput data penyusunan RBA tapi bukanlah penyusun. Penyusun RBA unit adalah Kaprodi yang terbentuk dalam tim adhock penyusunan RBA unit. Hal yang sama juga di jelaskan oleh bagian Perencanaan Universitas bahwa Unit memang belum memahami cara penyusunan anggaran berbasis kinerja sehingga hampir seluruh unit ketika dilakukan ferivikasi masih terdapat kegiatan yang tidak cocok dengan indikator dalam matriks. Dari hal tersebut dapat disimpulkan bahwa sebelum melakukan asistensi tingkat kementerian oleh bagian perencanaan maka perlu asisitensi pada tingkat Universitas. Seluruh kegiatan yang diusulkan oleh Universitas pada level kementerian harus dapat menunjukan dampak bagi peningkatan layanan dengan merujuk pada indikator yang ada. Ketercapaian dari indikator yang ada maka secara keseluruhan dapat terbaca sasaran yang ajukan di capai oleh Universitas. Oleh karena itu asistensi pada tingkat Universitas untuk mendapat gambaran tentang sasaran dari kegiatan yang diusulkan unit tepat dibawah indikator tertentu. Selain harus merujuk pada indikator dimana indikator tersebut merupakan turunan dari RSB yang telah di rumuskan institusi juga perlu di perhatikan besaran pagu yang dialokasikan.

\section{Alokasi Anggaran}

Alokasi anggaran dari Undana pada tahun 2018 menggunakan perhitungan dari kategori besaran pendapatan. Alokasi anggaran yang diberikan oleh Universitas kepada unit dan Fakultas mengunaka pola 40 : 60 artinya 40 persen anggaran ada pada tingkat Rektorat dalam rangka pembayaran tunjangan kinerja atau remunerasi pegawai negeri 
sipil (PNS) dan 60 persen ada di tingkat Fakultas untuk operasional dan kegiatan layanan lainnya. Hasil pembagian tersebut diambil berdasarkan rapat pimpinan seluruh Unit dengan pimpinan Universitas. Hal ini mendapat perhatian yang cukup dari bagian perencanaan karena dalam mengusulkan program dan kegiatan harus juga berpatokan pada pagu yang dialokasikan bagi unit tersebut. Adalagi mekanisme lain yang diterapkan berupa aturan Rektor tentang batasan alokasi anggaran diantaranya alokasi anggaran perjalanan dinas maksimal $5 \%$ persen dari total pagu unit, minimal alokasi anggaran 7,5\% untuk kegiatan Penelitian, Minimal alokasi anggaran 5\% untuk kegiatan Kemahasiswaan, Minimal alokasi anggaran 20\% untuk belanja Modal dan sisanya untuk operasional perkantoran unit dan kegiatan lainnya. Hal ini dilakukan untuk meminimalkan kegiatan yang memiliki dampak rendah bagi perkembangan institusi. sebenarnya persoalan penyusunan RBA unit berbeda dengan penyusunan rencana kegiatan biasa dalam pola satker, dalam pola BLU, perencanaan program dan kegiatan dengan pola RBA perlu sedikit pengorbanan yang harus dijalani karena ada banyak faktor yang benar-benar merupakan hal baru. Karena merupakan hal baru mulai dari filosofi dari BLU sampai pada perencanaan yang strategis dengan menerapkan strategis bisnis dalam perencanaan perlu kecermatan. Hal ini dilakukan karena dalam melakukan pelayanan berupa program dan kegiatan di kaitkan dengan pola bisnis, ada hitungan untung dan rugi sehingga kita dipacu untuk benar-benar melakukan perhitungan yang valid dengan tidak mencari keuntungan.

\section{Perlu dilakukan Kolaborasi dan Koordinasi}

Universitas Nusa Cendana (Undana) sebagai suatu kesatuan sistem yang utuh dalam melasanakan tugas, fungsinya dan tanggungjawabnya sebagai satker BLU yang bergerak di bidang pendidikan, dalam pelaksanaannya wajib menyusun program dan kegiatan serta anggaran yang akan di gunakan dalam mencapai tujuan yang telah di tetapkan. Dalam hal penyusunan rencana bisnis anggaran unit sebagai bagian yang tidak terpisahkan dari rencana bisnis anggaran Universitas maka kolaborasi dan koordinasi antara unit pengguna anggaran harus diperkuat. Penyusunan Rencana Bisnis Anggaran universitas merupakan akumulasi dari setiap unit pengguna anggaran yang terbentuk secara sistem. Oleh karena itu kolaborasi merupakan hal mutlak yang wajib di lakukan 
demi terciptanya suatu rencana yang baik bagi peningkatan layanan kepada masyarakat juga tercapaianya tujuan yang ditetapkan institusi.

\section{Pengajuan dan Penetapan RBA Universitas}

Hasil Rancangan RBA satker BLU, selanjutnya akan di bahas oleh pihak berwenang yaitu Kementerian Keuangan akan menghasilkan DIPA. Sebelumnya Rektor sebagai pimpinan satker BLU harus mengajukan usulan RBA kepada Kementerian Ristekdikti untuk dibahas dan diseleraskan dengan kementerian sebagai bagian dari Rencana Kegiatan dan Anggaran Kementerian dan Lembaga (RKA-K/L). Usulan RBA tersebut disertai dengan usulan standar pelayanan minimum dan biaya dari keluaran (output) yang akan dihasilkan. RBA yang telah disetujui oleh Menteri atau Pimpinan Lembaga diajukan sebagai bagian dari RKA-KL kepada Menteri Keuangan dalam hal ini pada Direktur Jenderal Anggaran.

\section{Pengintegrasian RBA dengan RPJM Nasional}

Rencana Bisnis Anggaran (RBA) tidak berdiri sendiri, melainkan RBA tetap bagian dari APBN. Pendapatan BLU didalam RBA akan dikonsolidasikan menjadi Pendapatan yang sah, sedangkan biaya BLU akan dikonsolidasikan ke dalam RBA sampai pada anggaran belanjanya. Oleh karena itu, program dan kegiatan disusun dalam bentuk Rencana Bisnis Anggaran yang mengacu pada Rencana Strategis Bisnis yang kemudian di sesuaikan dengan Rencana Kerja dan Anggaran Kementerian Negara dan Lembaga (RKA-KL) dalam hal ini Kemenristekdikti yang tentunya sudah harus di sesuaikan dengan Rencana Pembangunan Jangka Menengah (RPJM) Nasional.

\section{Mekanisme Pengwasan Penyusunan RBA}

Ada beberapa unit yang mengusulkan kegiatan yang sudah seharusnya tidak relevan lagi dengan kondisi saat ini. Hal ini juga menunjukan bahwa unit memang menyusun kegiatan berdasarkan kegiatan yang sudah lalu tanpa ada revitalisasi program. Jika direview dan ternyata harus dirubah maka unit kesulitan mencari kegiatan yang relevan. Hal ini dikarenakan kurang internalisasi filosofi dari BLU dan terhadap RBA. Ada lagi faktor dari belum adanya aturan rektor yang mewajibkan unit untuk melakukan kolaborasi antar unit atau antar bagian. Hal ini tercermin dari beberapa indikator yang tidak tercapai karena tidak adanya kolaborasi tersebut dapat dikatakana bahwa kolaborasi unit dengan puskom untuk senantiasa menyajikan informasi kegiatan 
unit kepada masyarakat lewat website Undana, ada lagi kegiatan penelitian dosen pada prodi tidak tercatat dan tidak terupload pada aplikasi penelitian pada Lembaga Penelitian dan Pengabdian kepada Masyarakat (LP2M) dan ada berbagai kegiatan lainnya termasuk indikator opini laporan keuangan Wajar Tanpa Pengecualian biasa disingkat WTP yang hanya di bebankan pada bagian Keuangan, pada hal WTP merupakan bagian tidak terpisahkan dari perencanaan yang baik.

\section{KESIMPULAN}

Berdasarkan hasil pembahasan penelitian Kolaborasi dan koordinasi penyusunan RBA Universitas Nusa Cendana tahun 2018, maka dapat diambil kesimpulan sebagai berikut :

1. Penyusunan Rencana Bisnis Anggaran (RBA) merupakan salah satu dokumen penting pada satker Badan Layanan Umum (BLU). Penyusunan RBA ini mulai dilakukan setelah Penetapan Undana sebagai satker BLU. Sistem penyusunan RBA dimulai dari unit terbawah (bottom up) yakni Program Studi atau Fakultas sampai pada tingkat Universitas.

2. Penyusunan RBA dibutuhkan kolaborasi dan koordinasi intensif antar unit dengan Universitas sehingga adanya sinkronisasi program dan kegiatan dalam penyusunan RBA Universitas sesuai mekanisme yang berlaku. Kolaborasi dan koordinasi belum dilakukan secara efektif dan efisien. Hal ini menyebabkan adanya perbedaan pemahaman dan pengertian tentang RBA diantara level unit dengan Universitas, penjelasan tentang RBA yang kurang optimal sehingga adanya multi tafsir dan belum adanya regulasi yang mewajibkan adanya kolaborasi dan koordinasi antar unit untuk mencapai keefektifan penyusunan RBA.

\section{SARAN}

Berdasarkan uraian hasil analisis terhadap Kolaborasi dan koordinasi penyusunan RBA Universitas Nusa Cendana tahun 2018 maka, penulis memberikan saran sebagai berikut :

1. Perlu sosialisasi dan internalisasi tentang RBA dari level universitas ke unit unit untuk membangun pemahaman dan kesamaan pikir dalam penyusunan RBA. 
2. Perlu ada peraturan Rektor tentang penyusunan RBA dalam membangun kolaborasi dan koordinasi

3. Perlu adanya partisipasi atau pro aktif dari berbagai elemen terkait dalam penyusunan RBA

\section{DAFTAR PUSTAKA}

Abdulsyani. 1994. Sosiologi Skematika, Teori, dan Terapan. Jakarta: Bumi Aksara.

Ahmadi, Abu. 2004. Sosiologi Pendidikan. Jakarta: PT.Renika Cipta.

Basuki, Johanes. 2018. Administrasi Publik : Telaah Teoritis dan Empiris. Depok : Rajawali Pers.

Benu Agustinus. 2009. Bahan Ajar Metode Metode Penelitian Administrasi Publik.

Program Pascasarjana Universitas Nusa Cendana, Kupang Nusa Tenggara Timur (NTT).

Djumara, Noorsyamsa. 2008. Modul 4 Pengembangan Budaya Kerja Aparatur, Diklat Teknis manajemen Sumber Daya Manusia Pegawai Negeri Sipil (Human Resource Management). Departemen Dalam Negeri dan Lembaga Administrasi Negara.

Djumara, Noorsyamsa. 2008. Negosiasi, Kolaborasi dan Jejaring Kerja. Jakarta : Lembaga Administrasi Negara Republik Indonesia.

Dwiyanto, Agus. 2010. Manajemen Pelayanan Publik: Peduli Inklusif dan Kolaboratif.

Yogyakarta : Gajah Mada University Press.

Dwiyanto, Agus. 2012. Manajemen Pelayanan Publik : Peduli, Inklusif, dan Kolaboratif. Yogyakarta : Gadjah Mada University Press.

Emilia, Emi. 2009. Menulis Tesis dan Disertasi . Cetakan ke 2. Bandung: Alfabeta 2014. Koordinasi dan Kolaborasi. Jakarta : Bahan ajar Diklat Kepemimpinan Aparatur Pemerintah Tingkat IV Lembaga Administrasi Negara Republik Indonesia.

Emily R. Lai, Collaborations: A Literature Review, (Pearson, 2011)

Erly Suandy.2001. Perencanaan Pajak, Edisi 1. Jakarta : Salemba Empat.

Fahrudin, Ikhwan. (2018). Generasi Millenial di Era Revolusi Industri 4.0. Diakses 1/4/2019. Tersedia di http://bloktuban.com/2018/10/07/generasi-millenial-di-era$\underline{\text { revolusi-industri40/ }}$ 
Gasperz, Vincent. 2005. Sistem Manajemen Kinerja Terintegrasi Balanced Scorecard Dengan Six Sigma Untuk Organisasi Bisnis dan Pemerintah. Jakarta : Gramedia Pustaka Utama.

Keban, Yeremias T. 2007, Pembangunan Birokrasi di Indonesia: Agenda Kenegaraan yang Terabaikan, Pidato Pengukuran Guru Besar pada Fakultas Ilmu Sosial dan Ilmu Politik Universitas Gadjah Mada Yogyakarta.

Kementrian Komunikasi dan Informatika Republik Indonesia. (2016). Mengenal Generasi Millenial. Diakses 1/4/2019. Tersedia pada laman: https://www.kominfo.go.id/content/detail/8566/mengenal-

generasimillennial/0/sorotan_media

Keputusan Kementerian Keuangan Republik Indonesia Nomor 166/KMK.05/2017 tentang Penetapan Universitas Nusa Cendana Pada kementerian Riset Teknologi dan Pendidikan Tinggi sebagai Instansi Pemerintah yang menerapkan pola Pengelolaan Keuangan Badan Layanan Umum

2016, Pedoman Proses Perencanaan Penganggaran Dan Pelaksanaan Anggaran Edisi Revisi I. Jakarta: Kementerian Keuangan.

Kusnandar. 2013. Penilaian Autentik (Penilaian Hasil Belajar Peserta Didik Berdasarkan Kurikulum 2013). Jakarta : Rajawali Press.

Malayu, S.P Hasibuan. 2011. Manajemen Sumber Daya Manusia. Jakarta: Bumi Aksara Moleong, Lexy. 2013. Metodologi Penelitian Kualitatif. Bandung : Remaja Rosda Karya.

Moleong, Lexy.J. 2006. Metodologi Penelitian Kualitatif. Bandung : PT Remaja

Nasir, Mohamad. 2019. Sambutan pada Puncak peringatan Hari Pendidikan Nasional tahun 2019. Jakarta. Kemenristekdikti

Nawawi, Hadari. 1984. Administrasi Pendidikan. Jakarta: Gunung Agung.

Nawawi, Hadari. 2011. Manajemen Sumber Daya Manusia : Untuk Bisnis Yang Kompetitif. Yogyakarta : Gajahmada University Press.

Octorano, Donny Feronika. 2015. Pengaruh Koordinasi, Kompetensi Dan Disiplin Terhadap Kinerja Pegawai Unit Layanan Pengadaan Kementerian Agama Pusat (Ulp Kemenag Pusat). Jurnal MIX, Volume V. Universitas Brawijaya. 
Peraturan Direktur Jenderal Perbendaharaan Nomor Per-20/PB/2012 Tentang Pedoman

Teknis Penyusunan Rencana Bisnis Dan Anggaran Satuan Kerja Badan Layanan Umum.

Peraturan Menteri Keuangan No 92/PMK.05/2011 Tentang Rencana Bisnis Dan Anggaran Serta Pelaksanaan Anggaran Badan Layanan Umum

Peraturan Pemerintah Nomor 23 Tahun 2005 tentang Pengelolaan Keuangan Badan Layanan Umum

Pitri, T, Anisa. 2017. Kolaborasi Pemerintah Dan Masyarakat Dalam Penyelenggaraan Pendidikan: Pendidikan Khusus Di Provinsi Riau Tahun 2015-2016. Jom FISIP Volume 4. Universitas Riau.

Raharja, Sam'unJaja. 2009. Kolaborasi Sebagai Strategi Bisnis Masa Depan. Jurnal Administrasi Bisnis, Vol.5. Fisip Universitas Padjadjaran.

Riduwan. 2008. Metode dan Teknik Penyusunan Tesis. Bandung : Alfabeta

Riskasari, NurbiahTahir. 2018. Kolaborasi Aktor Pembangunan dalam Mewujudkan Desa Mandiri di DesaBongki Lengkese Kecamatan Sinjai Timur Kabupaten Sinjai. Makasar: Jurnal Ilmiah Ilmu Administrasi Publik: Jurnal Pemikiran dan Penelitian Administrasi Publik, Volume 8.

Rustiadi, Ernan, Dkk. 2011. Perencanaan dan Pengembangan Wilayah. Jakarta: Yayasan Pustaka Obor Rakyat.

Sari, Ria (dkk) 2015. Analisis Pengaruh Koordinasi, Komunikasi, Dan Pelayanan Publik Terhadap Efektifitas Penyelenggaraan Ibadah Haji (Studi Kasus Pada Kementerian Agama Kota Pangkalpinang). Jurnal Ilmiah Progresif Manajemen Bisnis (JIPMB), Volume 5.

Soesatyo, Bambang. (2018). Generasi Milenial dan Era Industri 4.0. Diakses 1/4/2019.

Tersedia di https://news.detik.com/kolom/3981811/generasi-milenial-dan-eraindustri40?fa=detik.callback \&code=bWFgF71P3OglRkE4Sys09le8FIRPFk

Somantri, M. 2014. Perencanaan Pendidikan. Bogor : IPB Press.

Subarsono, Agustinus. 2016. Kebijakan Publik dan Pemerintahan Kolaboratif, Isu-isu Kontemporer. Yogyakarta: Gava Media.

Sudarmo. 2011. Isu-isu Administrasi Publik dalam Perspektif Governance. Surakarta : Percetakaan UNS. 
Sugiyono. 2012. Metode Penelitian Pendidikan Pendekatan Kuantitatif, Kualitatif, dan $R \& D$. Bandung: Alfabeta.

Syafiie, Inu Kencana. 2011. Manajemen Pemerintahan. Jakarta: Pustaka Reka Cipta

Syafri, Wirman. 2012. Studi tenteng Administrasi Publik. Jakarta: Penerbit Erlangga.

Taliziduhu, Ndraha. 2011. Kybernologi 1 Ilmu Pemerintahan Baru. Jakarta: Rineka Cipta

Taufiqurokhman. 2008. Konsep dan Kajian Ilmu Perencanaan. Jakarta: Fakultas Ilmu Sosial dan Ilmu PolitikUniversitas Prof. Dr. Moestopo Beragama

Usaman, Suryani (Ed). 2014. Manajemen: Teori, Praktik dan Riset Pendidikan. Jakarta : Bumi Aksara.

Usman, Husaini. 2011. Metodologi Penelitian Sosial. Jakarta : PT Bumi Aksara.

Wibawa, Sutrisna. 2012. Implementasi Pengelolaan BLU Di Perguruan Tinggi (Pengalaman UNY). Disampaikan dalam Workshop Persiapan Menuju PK BLU UGM sebagai Upaya Mewujudkan Good University Governance Tahap II. 